\title{
Analysis of Oral Skills Development in the Most Used English Language Textbooks in the Second year of Baccalaureate in Spain
}

\author{
Gloria LuQue Agulló \\ University of Jaén \\ M. ${ }^{\text {a }}$ Camino Bueno-Alastuey \\ Public University of Navarre
}

Received: 29 November 2015 / Accepted: 31 July 2016

ISSN: $1697-7467$

\begin{abstract}
This paper examines oral/aural competence in the most commonly used coursebooks in the second year of Baccalaureate in Spain. Using a checklist created and validated in a former pilot analysis (Bueno-Alastuey and Luque Agulló, 2015a), five textbooks were analysed. Results showed that the proportion of tasks ${ }^{1}$ devoted to oral/aural and written skills was similar, that the level introduced was B1 according to the Common European Framework for Languages (CEFR), and that the methodological approach used was consistent with current pedagogical schemes. This suggests that Spanish coursebooks are following the CEFR requirements on oral/aural aspects, overlooking the written focus of the University Entrance exam.
\end{abstract}

Keywords: Oral skills, listening, speaking, second year of Baccalaureate, textbook evaluation.

Análisis del desarrollo de las destrezas orales en los libros de texto mas utilizados en el segundo curso de Bachillerato en España

RESUMEN: Este trabajo examina cómo se implementa la competencia oral en los libros de texto más usados en el último año de Bachillerato en España. Usando una herramienta validada en un estudio anterior (Bueno-Alastuey and Luque Agulló, 2015a), se analizaron cinco libros de texto. Los resultados muestran la misma proporción de tareas dedicadas al desarrollo de destrezas orales y escritas, un nivel B1 según el Marco de Referencia Europeo $(C E F R), \mathrm{y}$ un acercamiento metodológico enmarcado en las corrientes pedagógicas actuales. Estos resultados sugieren que los libros de texto siguen las directrices europeas en cuanto al desarrollo de las destrezas orales, ignorando el énfasis en los aspectos escritos del examen de acceso a la Universidad.

Palabras clave: Destrezas orales, recepción oral, producción oral, segundo de Bachillerato, evaluación de libros de texto.

${ }^{1}$ In this paper, tasks, activities and exercises will be used as interchangeable words. In textbooks, activities are considered as each of the exercises presented in which the learners are expected to "do" something, and they are usually numbered $(1,2,3$, etc). 


\section{INTRODUCTION}

Textbooks continue to play an essential role in English Language Teaching (ELT) classrooms all over the world (Mukundan and Ahour, 2010; Mukundan and Kalajahi, 2013). It is extremely common to see ELT professionals incorporating textbooks for daily teaching purposes and very few of them have not used or would not use published ELT materials at some stage of their career (Harmer, 2007; Mukundan and Ahour, 2010).

Even though the analysis of textbooks has been a fruitful area of research regarding both the focus of the studies and the settings of those analyses, studies focusing on how oral/aural competence is covered in coursebooks remain very limited (Cerezo, 2007; Mukundan and Kalajahi, 2013), and usually "involve making general, impressionistic judgements" (Littlejohn, 2011: 181). As oral/aural aspects of the language have become priorities for both educative authorities and learners, studying how this competence is attended to in textbooks should be of paramount importance as teachers tend to do in class what can be found in the textbook they are using (Littlejohn, 2011). And consequently, depending on how coursebooks deal with oral/aural aspects, communicative competence development might be affected (GomezRodríguez, 2010; Griffiths, 2013).

Following a previous pilot study in which the checklist used in this work was created, justified and validated (Bueno-Alastuey and Luque Agulló, 2015a), this paper analyses how textbooks address oral/aural competence development in the last year of Baccalaureate. This is the year when students take the high-stakes University Entrance exam ${ }^{2}$ in Spain.

\section{LANGUAGe TEACHING IN SPAin}

The development of the oral/aural aspects of communicative competence ${ }^{3}$ has not always been a priority in teaching foreign languages, as can be seen in many not-so young generations of learners and in older textbooks (Abu and Maarof, 2011; Cerezo, 2007; Padial and Tapia, 2007). However, since the onset of the Communicative approach in the 1980s, and especially since the development of the Common European Framework of Reference for Languages (CEFR) (Council of Europe, 2001), many institutions, teachers, and educational authorities have updated their views on the development of oral/aural competence in Europe and in Spain (Littlewood, 2007; Roldan et al., 2009). This change has affected the notion of what language teachers are supposed to teach, which has shifted from a set of concrete grammar-based notions to a series of communication-based competences involving the oral/aural skills.

In the case of Spain, the Laws of Education from the last two decades (LOE 2/2006; RD 1467/2007 and Decree 416/2008; LOMCE; BOE 295: 10/12/2013) consider students must be able to produce and take part in oral exchanges at the end of Baccalaureate levels.

\footnotetext{
${ }^{2}$ This exam focuses on written skills (reading and writing tasks), and vocabulary and grammatical aspects, but most of the regions in Spain do not consider oral aspects, either for comprehension or production.

${ }^{3}$ Even though the terms skill and competence are not interchangeable, oral/aural skills and oral/aural competence will be used in this paper to refer to both aural comprehension and oral production.
} 
These exchanges must not only be spontaneous, comprehensible and respectful but also fluent and accurate, making use of those strategies required by the communicative situation (RD 1467/2007). The most recent law (LOMCE) reinforces this idea suggesting that "both aural comprehension and oral production should be prioritized" (BOE 295: 97880). Subsequently, the notion of oral/aural competence development in the classroom is manifest and nowadays it constitutes the core of the Spanish Education system, following other European countries and the CEFR.

Despite this recent emphasis on oral/aural skills, the lack of oral communicative coverage is still prevalent in most Spanish University Entrance exams (Bueno-Alastuey and Luque Agulló, 2012; Spratt, 2005). This dichotomy between Spanish educational guidelines, which focus on oral/aural aspects, and the University Entrance exams, which focus on written skills, grammar and vocabulary, may also be reflected in the (oral vs. written) approach followed in the textbooks employed in the final year of Baccalaurate. Consequently, a systematic analysis and evaluation of those textbooks is required in order to shed light on the development of oral/aural aspects that might be taking place nowadays in Spain.

\section{Textbook evaluation}

Research on textbooks has traditionally focused on investigating general characteristics (Kirkgöz, 2009; Mukundan and Kalajahi, 2013), and has not probed deeply into oral/ aural skills development. However, even those general studies which have only analysed the general suitability of textbooks have reported an underdevelopment of communicative competence (Tomlinson, 2008).

More recent studies have turned their attention to specific communicative features. For example, Abu and Maarof (2011) analysed the oral communicative activities in the textbooks used in the third year of Secondary Education in Saudi Arabia and concluded that the books had mainly highly structured and controlled oral activities. Roldan et al. (2009) evaluated the presence of the communicative attainment criteria established by the CEFR for all skills in some common textbooks used in the first years of Secondary Education in Spain and pointed out that written skills were more adequately considered than oral/aural skills. Gomez-Rodriguez (2010) classified activities into mechanical, meaningful, and communicative practice and analysed the quantity of activities of each type that appeared in five English coursebooks representative of those currently used in Colombia. His results showed that all books emphasized grammar activities and mechanical and meaningful practice over communicative practice. Gilmore (2004) inspected the authenticity of dialogues in some coursebooks from the 1980 s to 2003 measuring pragmatic features, finding considerable differences between the textbook dialogues and their authentic equivalents. Carter (1998, in McCarty and O'Keefe, 2004) analysed textbook dialogues and concluded that they lacked core spoken language features such as ellipses, hedges, discourse markers or vague language. In addition, Criado and Sánchez (2009) determined the communicative orientation of tasks with a gradient from 1 to 10 in seven coursebooks used in Spain. They found out that more than half of the tasks proposed were communicative in nature but that their communicative potential and number decreased as they approached the second year of Baccalaureate, and thus, the high-stakes University Entrance final exam was closer. 
These studies have shed light on partial aspects of how oral/aural competence is addressed, and some (Criado and Sanchez, 2009) have pointed out a decrease in the communicative potential and nature of coursebooks in the last year of Baccalaureate prior to the University Entrance high-stakes exam. Consequently, given the lack of research on the oral/aural skills development potential of the textbooks used in this educational stage, and considering the reported potential negative washback effect the focus on written skills of that exam might have on oral/aural skills development (Amengual, 2009, 2010), it seems worth exploring how oral/aural competence is addressed in the most used coursebooks for this level all throughout Spain.

\section{Methodology}

\subsection{Design and Research questions}

This study followed a quantitative research design to study oral/aural skills development in some of the most used textbooks in the last year of Baccalaureate. With this objective in mind, the following research question was considered:

1. How are oral/aural skills addressed in the most used textbooks in the last year of Baccalaurate in Spain?

\subsection{Context and textbook selection}

In order to ensure representativeness, we sought information from major publishing houses about the three most used textbooks in the last year of Baccalaurate in seven communities: Navarre, the Basque Country, Castilla-La Mancha, Galicia, Andalucía, Cataluña and Logroño. According to the information obtained, a total of five coursebooks were selected for the analysis ${ }^{4}$.

To avoid advertising issues and other conflicts regarding course book choice, the information regarding the textbooks selected has been reduced to a minimum. Nevertheless, it should be mentioned that books are ordered according to their use, from most widely used (Book 1 used as the first option in four of the provinces selected) to least used (Book 5 used as the third option in one province).

\subsection{Instruments}

The instrument used to analyse the textbooks was a checklist created by the authors of this paper, and validated in a previous pilot study (See Bueno-Alastuey and Luque Agulló, 2015a). The tool was divided in four sections: an introductory/general section including background information, and three further sections, listening, speaking and pronunciation. Each specific section in turn included mechanical and meaning oriented processes, textual

\footnotetext{
${ }^{4}$ The five books analysed sold 134,654 copies in the last year of Baccalaurate in Spain in the year 2012, according to data provided by publishing companies.
} 
factors and learners' factors (for further details on the inclusion criteria and a justification see Bueno-Alastuey and Luque Agulló, 2015a).

\subsection{Procedure}

The checklist was first created and validated with an inter-rater agreement between the two raters for reliability of a Pearson's product correlation coefficient of 0.995 for numerical items, and a Cohen's Kappa correlation coefficient of 0.907 for categorical items. These results were significant and were interpreted as "excellent" according to Fleiss (1981) rules of thumb and significance.

After the validation of the checklist, each of the two raters analysed a further randomly selected unit from the three books from which a unit had already been analysed jointly, and two randomly selected units from the remaining two books. Thus, a total of ten randomly selected units (two units from each of the five books) were analysed.

All the data from the analysis were placed in an Excel spreadsheet and then grouped in tables to be analysed.

\section{RESUltS AND DISCUSSION}

The results of the analysis were divided into two categories. The first category included aspects related to the distribution of oral/aural skills development in the books. It comprised data regarding the amount or frequency of oral texts to be delivered or elicited from students, the length and the percentage of the unit devoted to each of the oral/aural skills, the distribution of the tasks within the units, the presence of extra-exercises in other parts of the textbook or in additional material, and the level of the tasks according to the CEFR (Council of Europe, 2001).

The second category examined aspects related to the features of the tasks/activities included in the textbooks in order to check whether the methodology used for oral/aural skills development was adequate (Ellis, 2005; McCarthy and O'Keeffe, 2004). The analysis included the focus of the tasks, their degree of control, their authenticity, the type of interaction shown or elicited, their integrated or isolated nature, the type of grouping proposed, the contextualized nature of the tasks, and finally, the existence of explicit strategy training within the units or in other sections.

\subsection{Oral skills organization / distribution}

As mentioned above, the first group of aspects considered what input (listening) was provided and what output (speaking) was expected from students in the textbooks analysed, as research (Gass, 2013) has pointed out the need of balancing input with production and practice to maximize learning outcomes. 


\subsubsection{Quantity, length, percentage of tasks devoted to each skill and proficiency level}

Table 1. Quantity of exercises, length and percentage in unit: Listening \& Speaking

\begin{tabular}{|c|c|c|c|c|c|c|c|c|c|c|}
\hline \multicolumn{11}{|c|}{ Listening } \\
\hline & \multicolumn{3}{|c|}{ Quantity } & \multicolumn{3}{|l|}{ Length } & \multicolumn{4}{|c|}{ Percentage } \\
\hline & $\begin{array}{l}2 \text { or } \\
\text { fewer }\end{array}$ & $3-5$ & $\begin{array}{l}\text { More than } \\
5\end{array}$ & $\begin{array}{l}\text { Less than } \\
3 \mathrm{~min} .\end{array}$ & $3-5$ & $\begin{array}{l}\text { More than } \\
5\end{array}$ & $\begin{array}{l}\text { Less } \\
\text { than } \\
20 \%\end{array}$ & $20 \%-40 \%$ & $\begin{array}{l}40 \%- \\
60 \%\end{array}$ & $\begin{array}{l}\begin{array}{l}\text { More } \\
\text { than } \\
60 \%\end{array} \\
\end{array}$ \\
\hline Book 1 & & & $\sqrt{ }$ & $\sqrt{ }$ & $\sqrt{ }$ & $\sqrt{ }$ & $\sqrt{ }$ & & & \\
\hline Book 2 & & & $\sqrt{ }$ & $\sqrt{ }$ & $\sqrt{ }$ & & $\sqrt{ }$ & & & \\
\hline Book 3 & & & $\sqrt{ }$ & $\sqrt{ }$ & $\sqrt{ }$ & $\sqrt{ }$ & L & $\sqrt{ }$ & & \\
\hline Book 4 & & & $\sqrt{ }$ & $\sqrt{ }$ & $\sqrt{ }$ & $\sqrt{ }$ & $\sqrt{ }$ & & & \\
\hline Book 5 & & & $\sqrt{ }$ & $\sqrt{ }$ & $\sqrt{ }$ & & & $\sqrt{ }$ & & \\
\hline \multicolumn{11}{|c|}{ Speaking } \\
\hline Book 1 & & & $\sqrt{ }$ & $\sqrt{ }$ & $\sqrt{ }$ & & & $\sqrt{ }$ & & \\
\hline Book 2 & & & $\sqrt{ }$ & $\sqrt{ }$ & $\sqrt{ }$ & & $\sqrt{ }$ & & & \\
\hline Book 3 & & & $\sqrt{ }$ & $\sqrt{ }$ & $\sqrt{ }$ & & $\sqrt{ }$ & & & \\
\hline Book 4 & & & $\sqrt{ }$ & $\sqrt{ }$ & $\sqrt{ }$ & & $\sqrt{ }$ & & & \\
\hline Book 5 & & & $\sqrt{ }$ & $\sqrt{ }$ & $\sqrt{ }$ & & & & $\sqrt{ }$ & \\
\hline
\end{tabular}

As the first section in Table 1 shows, all books included more than five audio materials in their units. However, their length tended to be shorter than 3 minutes, or between 3 and 5 minutes. Although this can be justified methodologically both for attention purposes and for the cognitive difficulties involved in listening (Rost, 2013), textbooks should include different kinds of input so that students experience extended input and all kinds of listening and speech phenomena. Fortunately, the book most used (Book 1) and Books 3 and 4 included audio materials of the three lengths.

Regarding the percentage devoted to aural comprehension in the units, it was less than $20 \%$ in three books, while two devoted between $20 \%$ and $40 \%$ of the units to its development. Considering the two books most used were among the three books devoting less than $20 \%$ of the units to listening, these proportions suggest a shortage of the input and time devoted to this skill in most books. These results also support previous findings stating that there seems to be an emphasis on reading, grammar and vocabulary development on coursebooks at this level (Gomez-Rodríguez, 2010; Roldán et al., 2009). Nonetheless, two of the books (Books 3 and 5) devoted enough percentage of the units to the development of listening.

Concerning speaking (see Table 1), all books had more than 5 speaking tasks in the units and all of them also had shorter (less than $20 \mathrm{~min}$.) and longer (between 10 and $20 \mathrm{~min}$.) speaking tasks, as expected for B1 levels. Consequently, all the books presented adequate tasks in quantity and length to develop and work oral output in class. Nevertheless, none of the books provided tasks longer than 20 minutes. The percentage of the unit devoted to speaking showed more variation than in listening. Most books (3) devoted less than $20 \%$ to this skill. The one most used in most provinces devoted between $20 \%$ and $40 \%$, and the remaining one devoted from $40 \%$ to $60 \%$ of the units to this skill.

Table 1 shows the levels of both receptive and productive skills according to the CEFR (Council of Europe, 2001). Most of the tasks were within a B1 level, although some provision was made for A2, which could be used to review, for background knowledge, or for reinforcement purposes. 
Summing up, both for listening and speaking, all books included an appropriate number of tasks, more than five, and their length was short to medium, which is a time interval expected in B1 levels for these skills. Regarding the percentage of the unit devoted to both skills, the majority of the books devoted less than $20 \%$ to each of those skills, and thus, still followed a similar pattern to the one already reported of dedicating more time and space to written than to oral skills (Gómez-Rodríguez, 2010; Roldán et al., 2009). However, a promising finding was that at least two books, including the most used one, devoted more than $20 \%$ of the unit to each of the oral skills.

\subsubsection{Distribution of tasks in units}

Regarding the type of exercises, the general tendency in textbooks was to include audio material and speaking activities as pre, while and post tasks for other skills. This shows the tasks were well-planned and there was integration of oral/aural and written skills in the coursebooks, allowing for the activation of background knowledge, and the recycling of previously seen linguistic material, thus maximizing learning outcomes (Gass, 2013).

With respect to the location of the receptive tasks within the units, listening tasks tended to be located in all positions. Productive tasks were also placed in all positions in all the books and, except Book 5, all the books included speaking tasks in the same place and always following the same order in all the units. Although this may be mechanical and monotonous to a certain extent and may impede the integration of skills advisable for successful language learning, it is also predictable and helpful in the sense that there is an explicit section for them.

\subsubsection{Extra-exercises provided}

With respect to extra listening exercises for homework or extra practice, the analysis showed very positive results, as all books provided extra listening activities for homework (HW) or for classroom work. The same happened with speaking, particularly in the teacher's book in all the books analysed. Three books (Books 1, 3 and 4) also provided opportunities for speaking as homework. This inclusion of extra practice of oral/aural skills might be representative of the gradual importance and consequent incorporation of oral/aural aspects in current teaching methodologies.

\subsection{Characteristics of the oral tasks}

The second category included in our study analysed the methodology applied to the development of oral/aural skills in the coursebooks considered. 


\subsubsection{Focus}

Table 2 shows the balance between tasks focused on linguistic aspects (accuracy) and on communicative aspects (fluency) for both receptive aural and productive oral skills.

Table 2. Levels of listening and speaking according to the CEFR

\begin{tabular}{|l|l|l|l|l|}
\hline & Listening & \multicolumn{3}{l|}{ Speaking } \\
\hline & A2 & B1 & A2 & B1 \\
\hline Book 1 & 0 & $18 /$ & $6 /$ & $24 /$ \\
& & 100 & 20 & 80 \\
\hline Book 2 & $9 /$ & $15 /$ & $9 /$ & $18 /$ \\
& 37,5 & 62,5 & 33,3 & 66,6 \\
\hline Book 3 & $7 /$ & $15 /$ & $4 /$ & $21 /$ \\
& 31,8 & 68,1 & 16 & 84 \\
\hline Book 4 & $23 /$ & $10 /$ & $11 /$ & $16 /$ \\
& 69,6 & 30,3 & 40,7 & 59,2 \\
\hline Book 5 & $16 /$ & $40 /$ & $18 /$ & $57 /$ \\
& 28,5 & 71,4 & 24 & 76 \\
\hline
\end{tabular}

In the listening and speaking sections of the table, the first column (Q) stands for the amount of exercises oriented towards accuracy, which in turn have been divided by the specific focus of the tasks into pronunciation (Pron), vocabulary (Voc) and grammar (Gram) exercises. The last column in each section (Comp in listening and Fluency in speaking) expresses the quantity of listening and speaking exercises oriented towards more communicative and meaning-oriented tasks. Therefore, those two columns show the number and percentage of tasks devoted to form-focused processes vs. meaning oriented ones.

The pronunciation section considers whether the pronunciation tasks include different types of focus on pronunciation features and deal with pronunciation at the segmental (Ind. Sounds), and suprasegmental level (stress and speech phenomena related to connected speech such as intonation).

From the results, it can be stated that listening was more oriented towards comprehension than towards accuracy in general (56\% vs. 43\%), and in all the books with varying degrees. Speaking was oriented towards fluency in general (62\% vs. 37\%), although two books showed a stronger orientation towards accuracy, suggesting those books were addressed to lower competence levels or more traditional oriented approaches.

In addition, there were more speaking tasks (207) than listening tasks (153), which also reflects a focus on output (Swain, 1995) or production (Ellis, 2005). These two facts, the orientation towards comprehension rather than accuracy and the higher amount of speaking activities show that books were oriented towards producing output, rather than emphasising lower level activities which would involve more input and be more guided, and thus, accuracy oriented outcomes.

Regarding pronunciation, there was a good balance of the three types of phenomena considered, as all the books except Book 3 covered segmental and supra segmental aspects. Thus, it can be stated that the work on pronunciation complements and contributes to the accuracy focus in both listening and speaking. 


\subsubsection{Degree of control of the tasks}

The degree of control of the listening tasks analysed varied from totally controlled exercises with a single correct response to more open exercises with different possible and correct answers, which involve higher comprehension, and also some expression ability. Within the category of closed exercises, there were seven possible options: matching, true/ false (T/F), fill in the gaps with options (Fill gaps Op), without options (Fill No opt), finding mistakes and rewriting. On the other hand, open exercises included three options: providing short written answers, longer written answers and essay-like answers based on notes or summarizing the content of an audio.

Results showed that the majority of the exercises to develop listening belonged to the category of closed exercises ( $83 \%$ vs. $13 \%)$. All books included the four first types of closed exercises (Matching, True and false, Multiple choice and fill-in-the-gaps with options given or without options). None of the books included finding mistakes or rewriting. Conversely, the amount of open exercises was very low in all the books, and all open tasks belonged to the category of providing short written answers. While methodologically, closed exercises could facilitate a focus on comprehension and are easier to correct as a clear cut answer can be provided, the scarce amount of open exercises may limit freer production processes.

Regarding the quantity and type of exercises provided for developing speaking, there were three main groups of tasks depending on their degree of guidance: i) structured tasks with guidance all throughout the task, ii) semi-structured tasks with some guidance but not throughout all the task, and iii) free activities without any guidance..

Similarly to listening, the lowest amount of speaking tasks were free tasks $(4,8 \%)$, followed by structured tasks $(26 \%)$ and semi-structured activities $(68 \%)$, the most frequent type. This suggests that speaking seems to be oriented towards both form and meaning, and that freer and only meaning focused tasks are scarce and limited to free conversations, while problem-solving tasks - which have been shown to produce a higher amount of talk (Swain, 2000; Willis and Willis, 2008) - were only present in one of the books once. These findings support other authors (Abu and Maarof, 2011; Chwyl, 2014) who had already shown the lack of freer, more communicative oriented tasks in textbooks.

Considering the development of pronunciation, all the books analysed included this aspect. All the books included a specific part where they worked on pronunciation on its own in the unit. Furthermore, three of them (Books 2, 4 and 5) had it integrated with listening or speaking. Following recent research findings (Birdsong, 2007; Moyer, 2004), all the books also included pronunciation both receptively and productively.

Regarding the type of pronunciation task, from the seven possible types ${ }^{5}$ of activities included in the checklist, the only ones included in all the books were "listening and repeat" and "identification of sounds" tasks. Three books included reading aloud activities, and only two dealt with discrimination activities or identification of stress activities. Intonation patterns were considered only once. These results show that there was more emphasis on segmental features and that productive pronunciation tasks were quite limited.

\footnotetext{
${ }^{5}$ The seven types of pronunciation tasks included in the checklist were listening and repeat, identification of sounds, discrimination practice with visual support, meaning contrasts with pictures, identification of stress and intonation, practicing pronunciation with sentences, rhymes, chants or songs or reading aloud.
} 


\subsubsection{Authenticity, type of speech and integration of skills}

Table 3. Focus of listening, speaking and pronunciation tasks.

\begin{tabular}{|c|c|c|c|c|c|c|c|c|c|c|c|c|c|}
\hline & \multicolumn{5}{|c|}{ Listening } & \multicolumn{5}{|c|}{ Speaking } & \multicolumn{3}{|c|}{ Pronunciation } \\
\hline & \multicolumn{4}{|c|}{ Mechanics } & \multirow{2}{*}{ Comp. } & \multicolumn{4}{|c|}{ Accuracy } & \multirow{2}{*}{ Fluency } & \multirow{2}{*}{$\begin{array}{c}\text { Ind } \\
\text { sounds }\end{array}$} & \multirow{2}{*}{ Stress } & \multirow{2}{*}{$\begin{array}{c}\text { Connected } \\
\text { speech }\end{array}$} \\
\hline & Q & Pron & Voc & Gram & & Q & Pron & Voc & Gram & & & & \\
\hline Book 1 & $\begin{array}{c}8 / \\
44,4\end{array}$ & $\sqrt{ }$ & $\sqrt{ }$ & $\sqrt{ }$ & $\begin{array}{c}10 / \\
55,5\end{array}$ & $\begin{array}{c}14 / \\
35 \%\end{array}$ & $\sqrt{ }$ & $\sqrt{ }$ & $\sqrt{ }$ & $\begin{array}{c}26 / \\
65 \% \\
\end{array}$ & $\sqrt{ }$ & $\sqrt{ }$ & $\sqrt{ }$ \\
\hline Book 2 & $\begin{array}{c}11 / \\
45,8 \\
\end{array}$ & $\sqrt{ }$ & $\sqrt{ }$ & $\sqrt{ }$ & $\begin{array}{c}13 / \\
54,1 \% \\
\end{array}$ & $\begin{array}{c}15 / \\
51,7 \\
\end{array}$ & $\sqrt{ }$ & $\sqrt{ }$ & $\sqrt{ }$ & $\begin{array}{c}14 / \\
48,2 \% \\
\end{array}$ & $\sqrt{ }$ & $\sqrt{ }$ & $\sqrt{ }$ \\
\hline Book 3 & $\begin{array}{c}9 / \\
41 \%\end{array}$ & $\sqrt{ }$ & $\sqrt{ }$ & $\sqrt{ }$ & $\begin{array}{c}13 / \\
59 \% \\
\end{array}$ & $\begin{array}{c}7 \\
21,8 \%\end{array}$ & $\sqrt{ }$ & $\sqrt{ }$ & $\sqrt{ }$ & $\begin{array}{c}25 / \\
78,1\end{array}$ & $\sqrt{ }$ & & $\sqrt{ }$ \\
\hline Book 4 & $\begin{array}{c}21 / \\
63,6 \\
\end{array}$ & $\sqrt{ }$ & $\sqrt{ }$ & $\sqrt{ }$ & $\begin{array}{c}12 / \\
36,3 \% \\
\end{array}$ & $\begin{array}{c}17 \\
54,8 \\
\end{array}$ & $\sqrt{ }$ & & $\sqrt{ }$ & $\begin{array}{c}14 / \\
45,1 \\
\end{array}$ & $\sqrt{ }$ & $\sqrt{ }$ & $\sqrt{ }$ \\
\hline Book 5 & $\begin{array}{c}18 / \\
32,1 \\
\end{array}$ & $\sqrt{ }$ & $\sqrt{ }$ & $\sqrt{ }$ & $\begin{array}{c}38 / \\
67,8 \\
\end{array}$ & $\begin{array}{c}25 \\
33,3 \% \\
\end{array}$ & $\sqrt{ }$ & $\sqrt{ }$ & $\sqrt{ }$ & $\begin{array}{c}50 / \\
66,6 \\
\end{array}$ & $\sqrt{ }$ & $\sqrt{ }$ & $\sqrt{ }$ \\
\hline & $43 \%$ & & & & $56 \%$ & $37 \%$ & & & & $62 \%$ & & & \\
\hline
\end{tabular}

Table 3 shows the proportion of authentic listening and speaking tasks (columns 1 and 5 ), whether they were integrated with other skills (columns 4 and 8), and the proportion of monologues and dialogues provided in listening and required for speaking tasks. Data show that there was a good balance between authentic and non-authentic ${ }^{6}$ tasks in listening -more than half of the tasks were authentic (57\%)- and an excellent balance in speaking $(72 \%$ authentic). In addition, the methodology was appropriate, as more than $50 \%$ of the two skills were always integrated with other skills as support ${ }^{7}$, except in Book 1.

Regarding the use of monologues versus dialogues/interactions, all the coursebooks ascribed to the CEFR requirements of introducing both monologues and interaction (dialogues). The units analysed show there were more monologues than interactions in the audio materials provided in three of the books (Books 2, 4 and 5), and equal or almost equal number of both types in Books 1 and 3. On the contrary, there were more interaction tasks than monologues in all books for the development of speaking.

\subsubsection{Type of students' arrangement/Groupings}

All books contemplated different groupings for the development of speaking (considering the average of 35 students per classroom, it is a fact speaking has to be organized in this way). Following the pattern of proposing more interaction tasks than monologues, the most common grouping proposed was pair work in all books (from $44 \%$ to $77,7 \%$ of the tasks were organized in pairs), followed by teacher-fronted tasks in which learners had to answer questions or give opinions to the teacher with all the class paying attention to the

${ }^{6}$ Authentic tasks involve language similar to authentic conversations with authentic or real-life tasks requiring some kind of understanding, not mechanical practice or aural recognition. In production, conversations would follow the same pattern. For further details on the notion of authentic materials, see McDonough and Shaw (2012).

${ }^{7}$ Integration of skills consisted on tasks in which students had to use more than one skill to successfully complete a task, for example reading a text and then listening to another text on the same topic to contrast the information, or speaking about a text in which students had to read some information beforehand, followed by a writing exercise again to finish a given task, for example a conclusion, a summary about the speaking task, etc. 
interaction teacher-student (from $22,2 \%$ to $46,6 \%$ ). Four of the books only presented those two kinds of groupings and only one book (Book 5) included small group (10,6\%) or big group tasks $(5,3 \%)$, in which more than two students had to develop an oral assignment without the teacher's intervention, for example sharing information, completing a project, etc.

The higher amount of pair work tasks is a promising finding as this grouping is a very good alternative for practicing speaking, it is easier to carry out and organize and it maximizes students' speaking time (Watanabe and Swain, 2007). Group work would also be a good option provided the number of students is small. However, only the least used book (Book 5) included this type of grouping.

\subsubsection{Context and type of support provided}

All textbooks provided a majority of contextualized tasks by including textual and/or visual support, in the form of images, drafts and/or pictures.

Data showed all the listening tasks included contextual cues in two books, and the remaining three presented approximately $70 \%$ of the tasks with context. This predominant inclusion of visual support is a positive finding as pictures, drafts or images may not only increase aural comprehension (Rost, 2013), but will also make textbooks more appealing/ attractive for students.

Regarding speaking tasks, all of them were contextualized in Books 1, 2 and 4, while almost all $(93,3 \%)$ had some kind of context in the remaining two books $(84 \%)$.

\subsubsection{Explicit strategy training and extra-exercises provided}

Explicit strategy training for listening ${ }^{8}$ was present in three of the books within the unit (Books 1, 3 and 4), and in two of those books (Books 1 and 4) there were also other sections in other parts of the textbook with explicit strategy training.

Explicit strategy training for speaking was scarcer. Only three books (Books 1, 2 and 4) had it both in the units and in another section of the textbook. The other two books (Books 3 and 5) included no explicit strategy training for speaking.

From the results (for more detailed information see Bueno-Alastuey and Luque Agulló, 2015b and Luque Agulló, Bueno-Alastuey and Ramos Álvarez, 2016), we could state that students are not trained extensively in the use of strategies, as would be needed to maximize learning (Griffiths, 2013), and consequently, more explicit strategy training should be introduced in the units, as being able to use strategies effectively increases comprehension and memory (Manchón, 2008), and improves learning (Cohen, 2011).

\section{Conclusion}

Regarding our research question of how oral/aural skills development are dealt with in some of the most used coursebooks in the last year of Baccalaureate in Spain, this analysis has shown there are enough receptive and productive tasks in all books analysed.

\footnotetext{
${ }^{8}$ When listening tasks in the course book unit include a chart, table, or extra information describing and recommending the use of a given learning strategy.
} 
Concerning textbook organization, oral production and aural reception had an adequate quantity of exercises and of enough length to provide speaking and listening practice. However, most books dedicated less than $20 \%$ to each of these skills, so the total amount of the unit dedicated to oral/aural skills development should be increased in the most used books. Additionally, our results suggest that there is still more dedication to the written skills, as reported by Gomez-Rodriguez (2010) and Roldán et al. (2009), and this may imply an implicit focus on the University Entrance Exam in Spain (washback effect: Spratt, 2005; Wall and Horak, 2006, 2011) or a faintly traditional oriented teaching approach.

Considering both skills in isolation, the proportion of speaking was higher than that of listening, indicating that production was emphasized over reception. However, many of the speaking tasks were teacher-fronted (in some of the books half or nearly half of the tasks), and thus, they could be considered aural input for the students, suggesting a balanced methodology (Swain, 1995; Ellis, 2005; Gass, 2013), or a more comprehensive choice of tasks being introduced for teachers to choose from. Additionally, the majority of tasks had a B1 level in all books and all provided extra material for aural comprehension and oral practice.

Regarding the CEFR requirements of including monologues and interaction (Council of Europe, 2001), listening included slightly more monologues, whereas there was more interaction than monologues in speaking, probably due to the difficulties involved in the production of monologues. Following this interactional pattern, there was a high rate of pair work activities, which have been shown to foster production (Watanabe and Swain, 2007), although they were balanced with a similar number of teacher-fronted tasks based on more traditional approaches.

Concerning additional methodological aspects, all tasks considered in textbooks had pre, while and follow up activities, all had integration with other skills, and all of them provided context, predominantly visual. The skills were usually in the same place and order, particularly in the case of speaking, and their focus was on meaning oriented processes rather than on form. However, most of the answers requested were semi-structured, thus controlled enough to allow certain degree of creativity but also a practical and economical rating process. Very few long productive answers were provided, and thus, there may be an important lack of real life communication and very limited freer negotiation of meaning (Abu and Maarof, 2011; Ellis, 2009; Gass, 2013).

Regarding pronunciation, all textbooks included receptive and productive tasks, and segmental and suprasegmental features. However, textbooks tended to focus more on sounds than on stress or intonation patterns, and production in context was only considered through reading aloud. Consequently, more focus on suprasegmental features and a greater variety in type of exercises and especially in productive exercises could be advised (Birdsong, 2009).

Even though previous studies (Criado and Sanchez, 2009) have pointed out a decrease in the communicative potential and nature of the tasks in the textbooks used in this last year, suggesting a potential negative washback effect (Amengual, 2009, 2010), our results point to a general tendency of considering oral/aural skills development sufficiently in the units in both receptive (McCarthy and O'Keeffe, 2004) and productive processes (Rost, 2013). Consequently, it could be stated that there is no apparent washback effect. Furthermore, communities with different University Entrance exams tend to choose similar textbooks independently of the type of skills tested in the exam. This may suggest that coursebooks 
are following the CEFR requirements of developing communicative competence rather than the particular situation determined by specific University entrance exams.

Thus, pedagogically speaking, oral/aural skills are being developed in textbooks in spite of the focus on written aspects of the entrance exam. This textbook orientation could suggest a gradual shift in the methodology followed in real classrooms, from a more traditional, grammar/writing focus to a more communicative oriented one. Publishing companies may be reflecting in their coursebooks what educational authorities and teachers require for their classrooms.

\section{REFERENCES}

Abu, Z. and Maarof, N. (2011). "Oral communicative activities in the Saudi third year secondary EFL textbooks", in Advances in Language and Literary Studies, 2,1: 7 -17.

Amengual, M. (2009). "Does the English Test in the Spanish University Entrance Examination influence the teaching of English?", in English Studies 90,5: 582-598.

Amengual, M. (2010). "Exploring the washback effects of a high-stakes English test on the teaching of English in Spanish Upper Secondary Schools", in Revista Alicantina de Estudios Ingleses, 23: $149-170$.

Bueno-Alastuey, M.C. and Luque Agulló, G. (2015a). "A tool to analyze oral competence development in EFL textbooks" Revista Española de Lingüística Aplicada/Spanish Journal of Applied Linguistics, 28(1): 73-96.

Bueno-Alastuey, M.C. and Luque Agulló, G. (2015b). Explicit instruction and implicit use of L2 learning strategies in higher secondary EFL course books. International Journal of English Studies, 15(2): 17.

Birdsong, D. (2009). "Age and the end state of second language acquisition", in W. Ritchie, and T. Bhatia (eds.), The new handbook of second language acquisition. Bingley: Emerald Group, 401-442.

Birdsong, D. (2007). "Nativelike pronunciation among late learners of French as a Second Language", in B. Ocke-Schwen and J.M. Murray (eds.), Language Experience in Second Language Speech Learning: In Honor of James Emil Flege. Amsterdam: John Benjamins Publishing, 99-116.

Cerezo, L. (2007). Investigación sobre las directrices curriculares relativas a la enseñanza de la lengua inglesa y su aplicación en el aula (1 ${ }^{\circ}$ de bachillerato) (Doctoral dissertation). University of Murcia, Spain. http://www.tesisenred.net/TDR-0114109-1143114

Chwyl, B. L. (2014). Linking grammar to CLB-based Materials: Theory to Practice (Doctoral dissertation). University of Alberta.

Cohen, A.D. (2011). "L2 learner strategies", in E. Hinkel (ed.), Handbook of research in second language teaching and learning, Vol. II - Part V. Methods and instruction in second language teaching. Abingdon, England: Routledge, 681-698.

Council of Europe (2001). Common European Framework of Reference for Language Learning, Teaching and Assessment. Cambridge: Cambridge University Press.

Criado, R. and Sánchez, A. (2009). "English language teaching in Spain: Do textbooks comply with the official methodological regulations? A sample analysis", in International Journal of English Studies, 9,1:1-28. 
Ellis, N. (2001). "Memory for language", in P. Robinson, (ed.), Cognition and second language instruction. Ernst Klett Sprachen, 33-68.

Ellis, N. (2003). "Constructions, Chinking and connectionism: The emergence of Second Language Structure" in C.J. Doughty and M.H. Long (eds.), The Handbook of Second Language Acquisition. Oxford: Blackwell Publishing Ltd, 63-103.

Ellis, R. (2005). Instructed second language acquisition: A literature review. Research Division, Ministry of Education.

Ellis, R. (2009). "The differential effects of three types of task planning on the fluency, complexity, and accuracy in L2 oral production", in Applied Linguistics, 30, 4: 474-509.

Fleiss, J.L. (2nd ed). (1981). Statistical Methods for Rates and Proportions. New York and London: Wiley and Sons.

Gass, S. M. (2013). Input, interaction and the second language learner. London and New York: Routledge.

Gómez-Rodriguez, L. (2010). "English Textbooks for Teaching and Learning English as a Foreign Language: Do They Really Help to Develop Communicative Competence?”, in Educación y Educadores, 13, available from: http://educacionyeducadores.unisabana.edu.co/index.php/ eye/article/view/1728/2330, accessed 1 December, 2015.

Griffiths, C. (2013). The Strategy Factor in Successful Language Learning. Multilingual Matters. UK: Clevedon.

Harmer, J. (2007). (4th ed.) The Practice of English Language Teaching. New York: Pearson Education.

Kirkgöz, Y. (2009). "Globalization and English language policy in Turkey", in Educational Policy, 23,5: 663-684.

Liao, X. (2003). Chinese secondary school teacher's attitude toward communicative language teaching and their classroom practice. Unpublished doctoral dissertation, University of Auckland.

Littlejohn, A. (2011). "The analysis of language teaching materials: inside the Trojan Horse", in B. Tomlinson (ed.), Materials Development in Language Teaching. Cambridge: Cambridge University Press, 179-211.

Littlewood, W. (2007). "Communicative and task-based language teaching in East Asian classrooms", in Language Teaching, 40:243-249.

Luque Agulló, G., Bueno-Alastuey, M.C. and Ramos Alvarez, M.M. (2016). Uso selectivo de estrategias según la destreza oral: un análisis de libros de texto de enseñanza del inglés usando la modelización categórica: Selective strategy use depending on oral skill: An analysis of EFL course books using categorical modelization. Revista de Educación, 374: 10-72

McCarthy, M. and O'Keeffe, A. (2004). "Research in the teaching of speaking", in Annual Review of Applied Linguistics, 24:26-43.

McDonough, J., and Shaw, C. (2012). Materials and Methods in ELT. John Wiley \& Sons.

Moyer, A. (2004). Age, Accent, and Experience in Second Language Acquisition: An Integrated Approach to Critical Period Inquiry. Clevedon: Multilingual Matters.

Mukundan, J., and Ahour, T. (2010). "A review of textbook evaluation checklists across four decades (1970-2008)", in B. Tomlinson and H. Masuhara (eds.) Research for materials development in language learning: Evidence for best practice. London: Continuum, 336-352.

Mukundan, J., and Nimehchisalem, V. (2012). "Evaluative criteria of an English language textbook evaluation checklist", in Journal of Language Teaching Research, 3,6: 1128-1134. 
Mukundan, J., and Kalajahi, S. A. R. (2013). "Evaluation of Malaysian English Language Teaching Textbooks", in International Journal of Education and Literacy Studies, 1,1:38-46.

Nicolson, M, and Adams, H. (2010). "The languages classroom: place of comfort or obstacle course?", in The Language Learning Journal, 38,1:37-49.

Padial, R., and Tapia, E. (2007). "The motivation to use oral language in the EFL classroom in ESO and Bachillerato", in Porta Linguarum, 7:135-151.

Roldan, A., Lucena, D.,Mesenger, L., Roldán, J., and Sanchez, M. (2009). “Adecuación de los libros de texto al Marco Común Europeo de Referencia para las Lenguas (MCERL)", in Porta Linguarum, 11:189-206.

Rost, M. (2013). Teaching and Researching: Listening. New York: Routlege.

Spratt, M. (2005): "Washback and the classroom: The implications for teaching and learning of studies of washback from exams", in Language Teaching Research, 9, 1: 5 - 29.

Swain, M. (1995). "Three functions of output in second language learning", in G. Cook, and B. Seidelhofer (eds.), Principle and Practice in Applied Linguistics: Studies in Honor of H.G. Widdowson. Oxford: Oxford University Press, 125-144.

Swain, M. (2000). "The output hypothesis and beyond: Mediating acquisition through collaborative dialogue", in J.P. Lantolf, and J.P. Lantolf, (eds.), Sociocultural theory and second language learning. Oxford: Oxford University Press, 97-114.

Tomlinson, B. (ed.) (2008). English Language Learning Materials: A Critical Review. London: Continuum.

Wall, D., and Horak, T. (2006). "The impact of changes in the TOEFL examination on teaching and learning in central and eastern Europe: Phase 1, the baseline study". TOEFL Monograph MS 34. Princeton, NJ: Educational Testing Service, available from: http://www.ets. org/portal/site/ets, accessed 1 December, 2015.

Wall, D., and Horak, T. (2011). "The impact of changes in the TOEFL examination on teaching and learning in central and eastern Europe: Phase 3, the baseline study". TOEFL Monograph MS 34. Princeton, NJ: Educational Testing Service, available from: http://www.ets. org/Media/Research/pdf/RR-11-41.pdf, accessed 1 December, 2015.

Watanabe, Y., and Swain, M. (2007). "Effects of proficiency differences and patterns of pair interaction on second language learning: Collaborative dialogue between adult ESL learners", in Language Teaching Research, 11,2:121-142.

Willis, D., and Willis, J. (2008). "Doing Task-Based Teaching", in TESL-EJ, 12(1).

Yu, L. (2001). "Communicative language teaching in China: Progress and resistance", in TESOL Quarterly, 35,1:194-179. 